\title{
小径ドリル型削孔試験機の開発之歴史的建造物の 表層強度測定への適用
}

\author{
長谷川哲也 ${ }^{* 1} ・$ 畑中重光 ${ }^{* 2} \cdot$ 三島直生*3 $・$ 谷川恭雄 ${ }^{* 4}$
}

\begin{abstract}
概 要 歴史的建造物に使用されている煉瓦・石材の表面は風化等の経年劣化が問題亡なっている。本研究では, 建造 物の損傷を最小限に抑え, 表層強度分布を微破壊によって計測する装置を開発することを目的として一連の研究を行った。 第一段階として, 試験機を試作した。第二段階として, 実際の現場でテラコッタの表層強度の評洒掞よび補修剂の効果確 認を行った。その結果, 釉薬および素地の相対的な強度分布の評価を行うことができた。第三段階として試験機の削孔速 度の安定化を図り，表層材料の強度を求めるため検量線の作成を行った。その結果，比較的均質な材料（煉瓦・石材・漆 喰・セメントペーストなど）の表層から内部方向への強度分布を精度良く測定できる可能性を示した。

キーワード：非破壊試験, 携帯式, 小径ドリル, 表層強度分布, 歴史的建造物, 構造体, ダイヤモンドビット
\end{abstract}

\section{1. 研究の背景}

エジプトのスフィンクスや神殿柱脚の劣化，ギリシャ のパルテ, ン神殿の柱の瘦せ, タイのアユタヤ遺跡の棟 瓦造仏塔の風化など，石造・棟瓦造文化財の劣化が問題 視されるなか，我が国でも墓石・石造建造物および煉瓦 造建造物の文化財が劣化し始めている。これらの劣化の 中で多くを占めているのは塩類風化と呼ばれる塩類 ( $\mathrm{NaCl}, \mathrm{Na}_{2} \mathrm{SO}_{4}, \mathrm{MgSO}_{4}$ など) の結晶膨張による表層の 脆弱化および剥落である ${ }^{1)}$ 。

日本で屯，いくつかの文化財建造物がこの塩類風化・ 凍害等ですでに劣化し始めている。写真-1は，現存す る日本最古のテラコッタの劣化で, 表面のレリーフが剥 落している。写真-2 は, 外壁棟瓦の劣化である。これ ら歴史的建造物はただ古いだけでなく，文化的価值・産 業遺産的価値が高く，地域のシンボルとなっている場合 屯多い。また，現在の技術レベルでは再現が難しいもの も少なくない。いわば人類にとってかけがえの無いもの であり，保存・修復は避けて通れない。これらに対し， 適切な保存・修復を行うには正確な現状把握および補修 効果の確認が不可欠となるが，材料面の物理性能評価を 現場で行う場合，既存の方法では測定值に対する信頼性 が低いこと，被測定体が限られることなどの問題がある。

現場に沶けるコンクリートの表層強度推定手法として は，以前上り行われている反発度法 ${ }^{5}$, コアドリル等の 送り難易度による推定法 ${ }^{5)>8)}$, 引っかき試験法5), 9), など がある。いずれも文化財等の実測では，測定の条件面や 精度面の課題を残している。

筆者らは，建造物の表層を，定回転・定圧力で削孔し，

*1 はせがわ・てつや/日本診断設計森) 代表取締役 (正会員)

*2 はたなか・しげみつ/三重大学大学院 工学研究科 教授（正会員

*3 みしま・なおき/三重大学大学院 工学研究科 助教 (正会員)

*4 たにがわ・やすお/名城大学 理丁学部 建築学科 教授 (正会員)

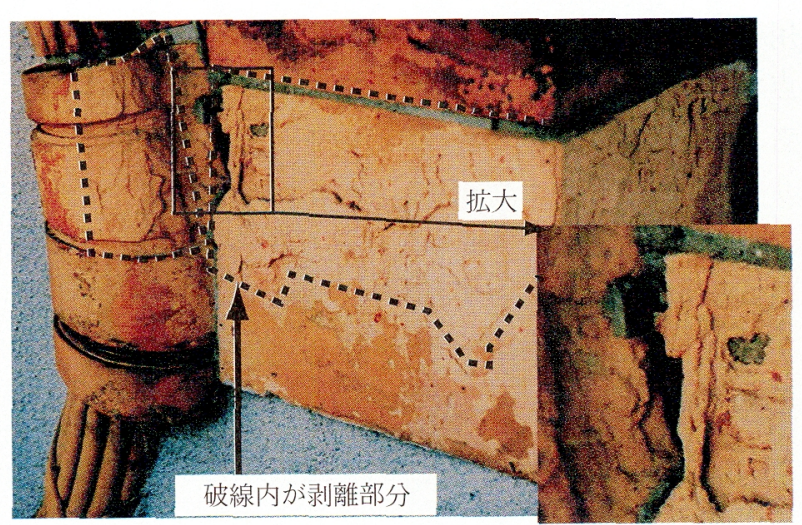

写真-1 テラコッタの劣化（京都府立図書館, 明治 42 年)

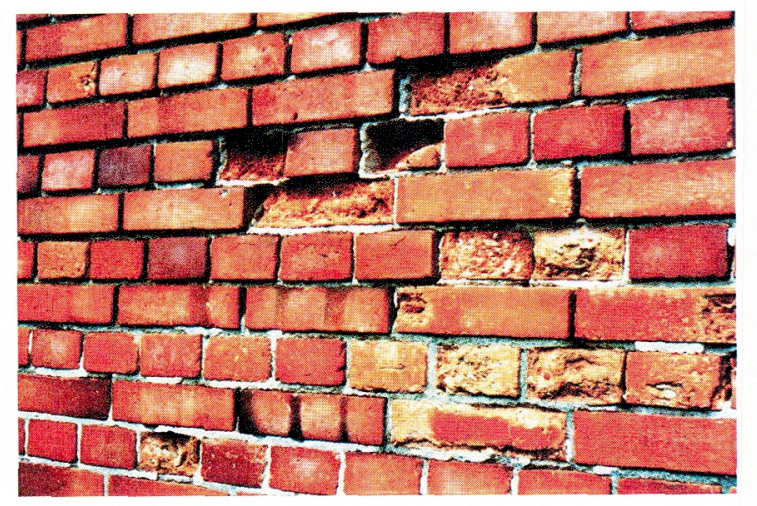

写真-2 棟瓦の劣化（大宝六角棟瓦蔵, 明治 41 年）

その削孔速度から被測定体の強度を推定することを目的 として，小型で携帯が可能な試験機之その試験方法を開

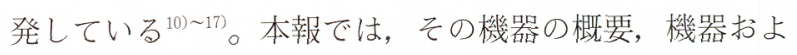
び試験方法の開発状況，文化財および一般建築物の診断・ 補修時に抢ける機器の適用例について紹介する。 
2. 削孔試験機方よび試験方法の概要々開発の 進渉状沉

\section{1 試験機の要求性能}

試験機に必要とされる性能は，以下の上おりである。

(1)表面から内部へ向けての連続した強度特性の評価が できること。

(2)現場で測定でき，その場で評価結果が判明すること。

(3)煉瓦・石材など，表面が平滑でなくても測定できる こと。

(4)塗装等が存在しても，除去せずにその上から測定で きること。

\section{2 試験機と測定のイメージ}

図-1に今回開発する削孔試験機のイメージ，写真-3 に同試験機の概観，図-2 に測定結果のイメージを示す。 この機器は, 一定のトルクおよび一定の回転数で稼働す るモー夕を組タ込んだ回転ドリルを一定の力で押しなが ら被測定体を削孔し，図-2 に示すように，その削孔速 度によって材料の強弱を評価するものである。

ここで，強度の相対評価については，図-2のように 削孔デー夕の傾きを比較することで，基準とする物質に 対する強弱の比較およびその範囲の評価を，また，絶対 評価については，この傾きを圧縮強度に变換することで 一般的な強度評価を行った。

\section{3 削孔試験機の構成部品}

(1) 定トルクモー夕

一般のドリル等に使用されているモー夕では被削孔体 の強度がある程度以上強くなり，削孔時の回転の抵抗が 増した場合には負荷トルクが上がり回転数が低下する。 これに対し，本機では定トルクモー夕を使用し，常に同 じ回転数で削孔できるように工夫した。

（2）定出力バネ

本機では，先端に削孔用ビットが取り付けられた回転
軸部を被削孔体に押しつけることによって削孔を可能と している。モー夕の出力さえ十分であ机ば，この押しつ

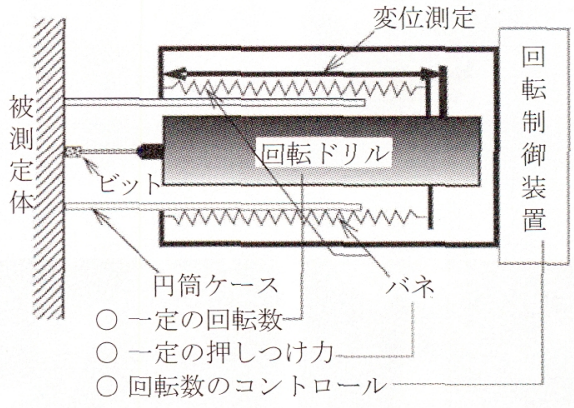

図-1 削孔試験機のイメージ図

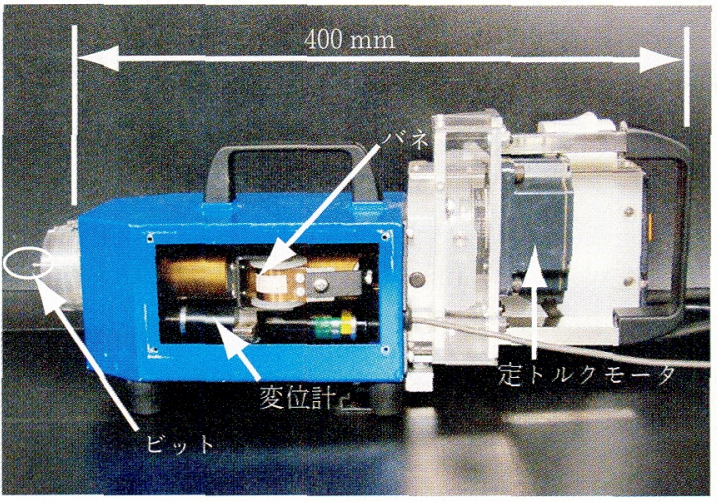

写真-3 試作した削孔試験機

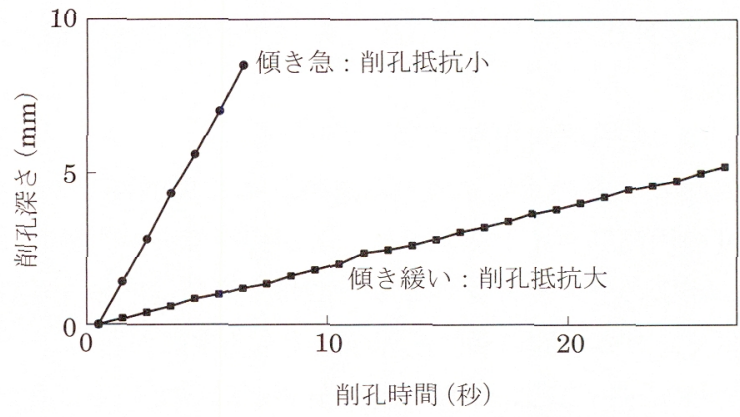

図-2 測定結果のイメージ図

Development of Drilling Type Surface Strength Tester and Estimation Method of Surface Strength of Historic Structures

By T. Hasegawa, S. Hatanaka, N. Mishima and Y. Tanigawa

Concrete Journal, Vol.46, No.6, pp.10 17, Jun. 2008

Synopsis As for historic structures, aged deterioration such as weathering is conspicuous on the surface of brick and stone structures. The purpose of the present study is to devise a tester which can measure surface strength distribution of structures by slight-destructive inspection. At the first stage, a tester was devised experimentally. Secondly, the actual surface strength and the effect of repairing chemical agent on terra cotta were tested, and the result demonstrated the possibility of definite evaluation of the relative strength and thickness of the glaze, and the relative strength of the foundation. Thirdly, a formula was drawn out for the estimation of absolute strength of surface material, trying to secure the stability of drilling speed. As a result, an accurate measurement of inner strength variation of relatively homogeneous materials (brick, stone, plaster, cement paste, and so on) was successfully demonstrated.

Keywords : non-destructive inspection, portable, small diameter drill, surface strength distribution, historic structure, structures, diamond bit 


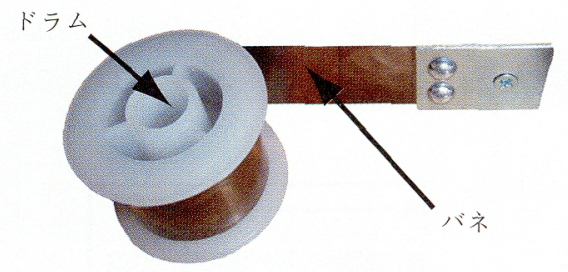

写真-4 定出カバネ

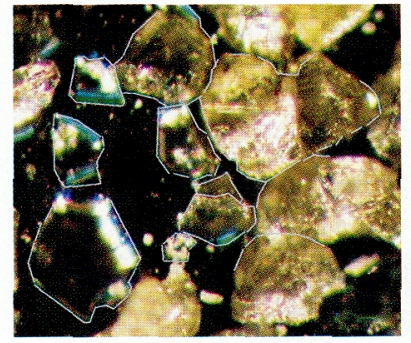

写真-5 市販品砥粒

(粒径は不揃い)

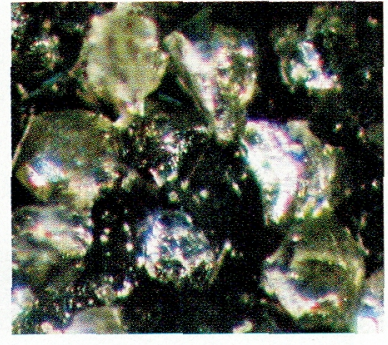

写真-6 専用ビット砥粒 （粒径はほぼ一定）
け力が大きいほど削孔速度は増す。ここで, 通常のコイ ルバネを利用すると，削孔深さが梁くなるにつれてバネ の張力が低下し，削孔速度に影響を及ぼしてしまう。そ こで本機では，ストロークによってバネの張力が变化し ない写真-4のような定出力八゙ネを採用し，バネの押し つけ力の変化を極力低減させた。内蔵する接触型变位計 のバネの影響も含めた本機の押しつけ力は，(10.50.08X) N となった。ここで，X は削孔深さ (mm) で ある。

（3）削孔試験用ダイヤモンドビット

先端ビットの選定試験 ${ }^{10)}$ の結果, 削孔性能は $\phi 3 \mathrm{~mm}$ 程度の円筒形ダイヤモンドビットが良好であった。ただ し，市販のダイヤモンドビットでは，削孔速度の安定性 が低く，ビット間の個体差等の誤差も非常に大きかった。 これはビットごとに砥粒の粒度分布が違っていることが 原因と推定されたため, 本研究では, ダイヤモンド砥粒 の粒度を \#60 に揃えた専用のビットを作製した。市販 品のダイヤモンド砥粒を写真 -5 に, 専用ビットの砥粒 を写真- 6 に示す。写真-5 抢よび写真-6 比較すれば, 市販品の砥粒の大きさが不揃いであることが分かる。

\section{4 測 定方法}

被測定体を試験機で削孔し，ビット先端の変位を 1 秒 ごとに自動計測した。計測した 1 秒ごとの变位が削孔速 度となり，その大小で強度評価を行った。

\section{5 開発の手順}

本開発研究全体の手順を図-3に示す。本研究では, 第一段階として，前項に述べたような試験機および試験 方法を開発し，第二段階として，煉瓦・石材・テラコッ 夕等の歴史的建造物の表層劣化等の評価を行った。歴史 的建造物では現状をいかに保存するかといったことが要 求されるため，第二段階の測定は，健全部に対する劣化 部の相対評価が主体となった。第三段階では，セメント

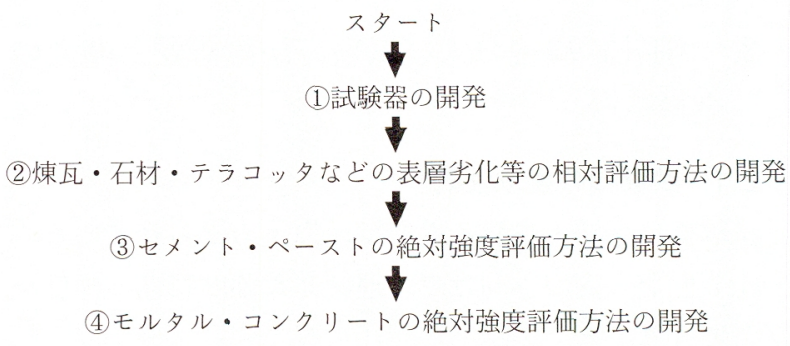

図-3 本研究の手順

硬化体の絶対強度の測定を行った。本報では，ここまで の研究を紹介するが，今後はコンクリート等の骨材が入っ た複合材料の評価について試験方法の開発研究を行う予 定である。

3. 歴史的建造物の外装テラコッタの表層劣化 評価 ${ }^{11 ~ 14)}$

\section{1 試 験目 的}

開発した試験機を実際の歴史的建造物で使用すること によって, 試験機としての基本性能を調べるとともに歴 史的建造物の表層劣化評価をどの程度の精度で行うこと ができるかを検証した。

評価対象は，1932 年に竣工した鉄骨鉄筋コンクリー 卜造 7 階建てで，現在も商業ビルとして活用されている 建物の外装テラコッタである。建物の外壁は，高さ約 $30 \mathrm{~m}$ ，長さ約 $200 \mathrm{~m}$ の大壁面となっており，テラコッ 夕と二丁掛け夕イルで装飾されている。当時の仕上技術 の粋を凝らした外観は素晴らしいものであり，地域のシ ンボルともなっている。しかし，近年このテラコッタに は度重なる補修跡・ひび割れ㧍よび釉薬の剥離などが目 立ちはじめ，意匠性・耐久性が問題視されるに至った。 今回は，劣化した部位と健全な部位の材料面での相違を 本試験機で評価することとした。

\section{2 試 験 概 要}

(1) 評価項目

1）テラコッタ表層部の評価

テラコッタ表層部の強度特性の評価を行った。ただし， ここでの評価項目は, テラコッタの釉薬の厚さと強さ, および素地の強さとしたが，文化財の修復は健全な状態 に戻すことが要求されるため, 強さは，劣化していない 釉薬抢よび素地を基準とし，相対評価を行った。また強 さの指標としては, 削孔試験器による削孔速度を用いる こととした。測定は，図-4に示すメダリオンと呼ばれ る形状のテラコッタについて行った。すなわち，目視・ 打診調查において，貫入（焼成時に釉薬に入った微細な ひびで，劣化ではなく㬻き物の風合いとされるもの）は 入っているものの釉薬の浮きむ剥離もないメダリオン （メダリオン 1 ：以下，M 1 上呼ぶ）上，釉薬の浮きお よび釉薬が剥離しているメダリオン（メダリオン 2 ：以 下，M 2 上呼ぶ）の同形状の 2 つのテラコッタで測定を 


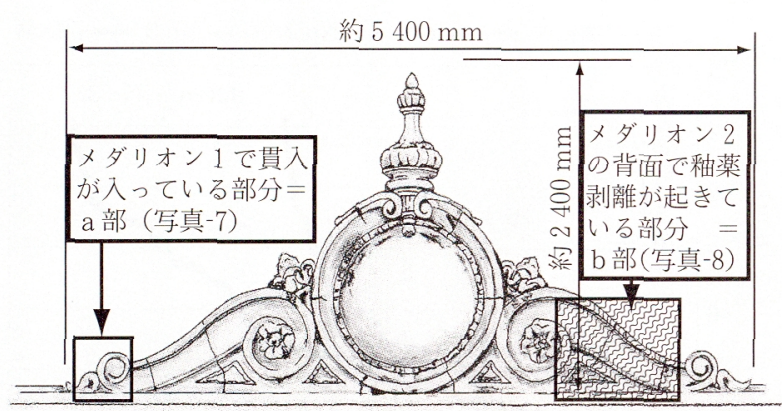

図-4 メダリオンの形状図

表-1 計測した部分

\begin{tabular}{|c|c|c|c|c|c|}
\hline \multirow{2}{*}{ テラコッ夕種別 } & \multirow{2}{*}{ 記 号 } & \multirow{2}{*}{ 健全部 } & \multicolumn{3}{|c|}{ 劣化部 } \\
\hline & & & 貫入部 & 嬏薬浮き部 & 釉薬剥離部 \\
\hline メダリオン 1 & M 1 & 0 & $0^{* 1}$ & & \\
\hline メダリオン 2 & M 2 & 0 & & 0 & $O^{* 2}$ \\
\hline
\end{tabular}

【注】○：計測した部分 $※ 1 ：$ 写真 -7 参照, $※ 2:$ 写真 -8 参照

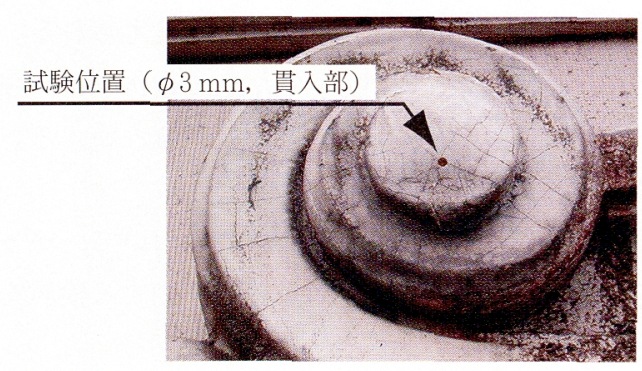

写真-7 メダリオン 1 の a 部（貫入が入った部分）

行った。2つのテラコッタの測定䇢所を表-1に示す。写 真-7および写真-8 には，それぞれＭ１の釉薬貫入部， およびM 2 の釉薬剥離部の削孔試験位置を示す。

2）含浸強化剤の浸透深さおよび品質改善効果に関す 当評価

釉薬層はテラコッ夕によって保護層でああるが，これ が剥離した部分は既に素地が脆弱化していることが想定 される。この劣化進行を停止・抑制させる材料として, 塗布するだけで素地を浸透強化させる薬郕を選定し，そ の効果を本試験機で評価した。含浸強化剂の評価用試験 体は，前述のメダリオンではなく，一般外壁面の平物テ ラコッタ $(450 \times 250 \times 40 \mathrm{~mm})$ とし，これをカットし て素地を露出させた部分に含浸強化剂を刷毛で塗布した。 塗布は，1 度塗った後，薬剂が素地に吸い込ま机るのを 待って次の塗布を行った。同様の作業を薬剤が素地汇吸 い込まれなくなるまで行った。薬剤の配合を表-2 に示 す。ここで，接着剂にはイソシアン酸エステルを使用し た。このテラコッタの含浸強化剤を塗布していない部分 を直径 $10 \mathrm{~mm}$ の円柱形に整形し, 圧縮試験を行う之上 屯に $110^{\circ} \mathrm{C}$ 乾燥後抢上び 24 時間吸水後に質量測定を行 い，吸水率を測定した。測定結果を表-3に示す。表-3 に上机ば，大正 13 年の JES 8 号普通棟瓦の「上焼 1 等 圧縮強度 $15 \mathrm{MPa}$ 以上，吸水 $18 \%$ 以下」の条件は満足

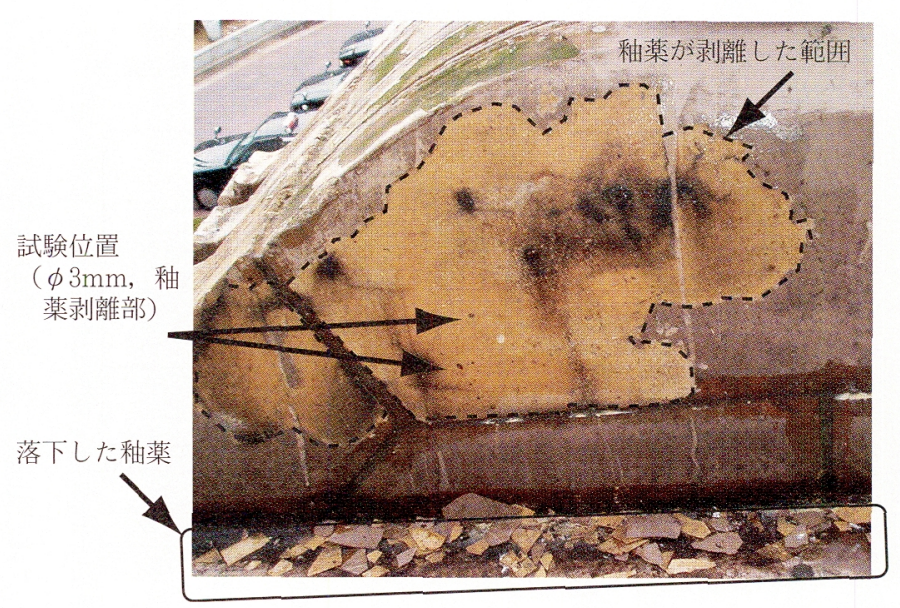

写真-8 メダリオン 2 の b 部 (釉薬剥離している部分)

表-2 含浸強化剂の配合比（重量比）

\begin{tabular}{|c|c|c|c|c|}
\hline No. & 接着剂 & シリコン & 反応剤 & 溶 剂 \\
\hline 1 & 1 & 0.8 & 0.2 & 1 \\
\hline 2 & 1 & 0.5 & 0.5 & 1 \\
\hline 3 & 1 & 0.01 & 0.79 & 2. 2 \\
\hline W & 1 & 0.5 & & 1.5 \\
\hline \multicolumn{5}{|c|}{$\begin{aligned} \text { 【注】接着剤 } & \text { : イソシアン酸エステル } \\
\text { シリコン } & \text { : シリコンコポリマー } \\
\text { 溶 剤 } & \text { : エステル系 }\end{aligned}$} \\
\hline
\end{tabular}

表-3 平物テラコッタの物性

\begin{tabular}{c|c}
\hline 圧縮強度 & $21.4 \mathrm{MPa}$ \\
\hline 吸水率 & $11.8 \%$ \\
\hline
\end{tabular}

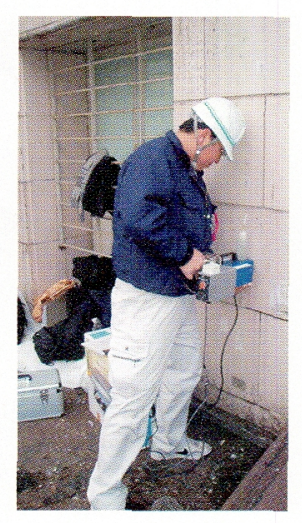

写真-9 現地試験状況

していることが分かる。

（2）試験方法

写真-9に，現地での試験状況を示す。テラコッ夕の 強度が弱かったため，削孔用ビットには，やや太径の 申5のダイヤモンド円柱を用いた。ただし削孔抵抗が大 きいと想定される含浸強化好理の評価には $\phi 3$ のビット を用いた。ドリルの回転数は $4000 \mathrm{rpm}$ とし, 削孔深さ は最大で約 $12 \mathrm{~mm}$ とした。

\section{3 試験結果および考察}

（1）テラコッタの表層部強度

M1 \M2 の各部の测定結果を図-5に示す。比較の

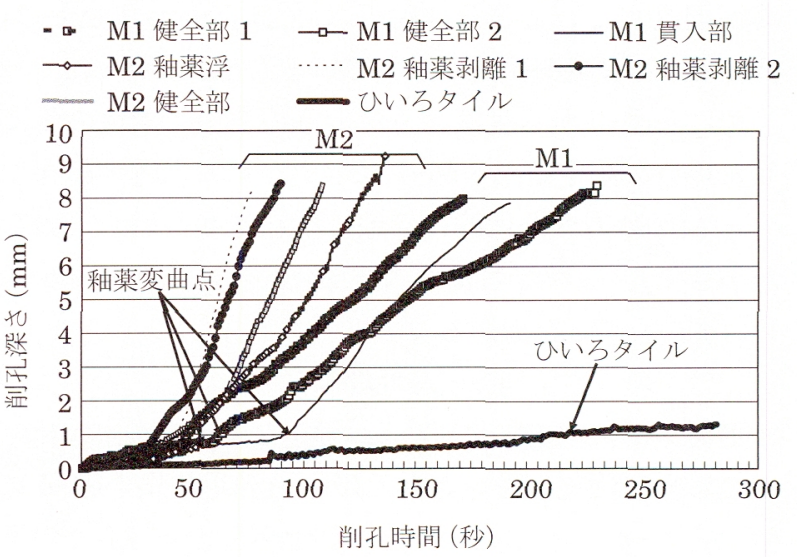

図-5 メダリオンの全削孔試験結果 


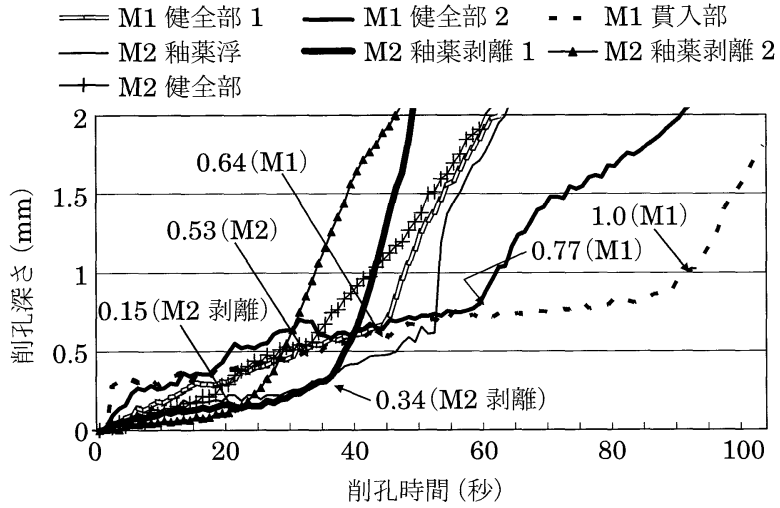

図-6 メダリオン表層部データの拡大図

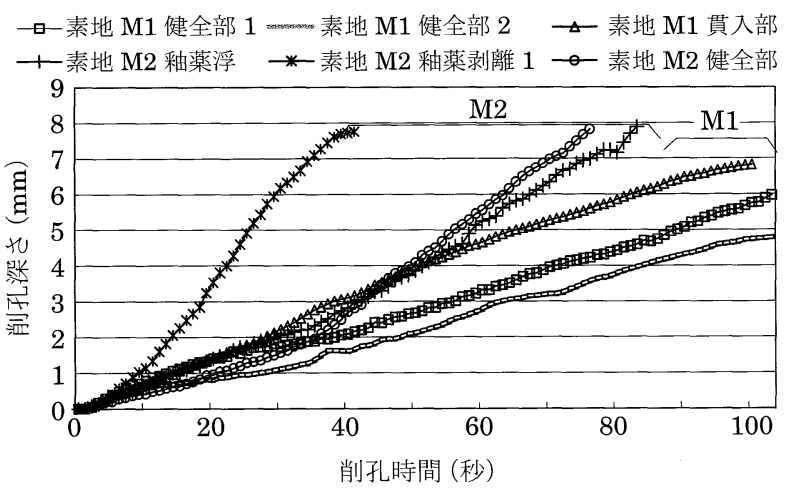

図-7 メダリオン素地のみの削孔試験結果

ため，現在よく使用されている，ひいろ夕イルについて あ測定した。ひいろ夕イルは無釉にもかかわらず削孔速 度が遅い，すなわち強度が高いことが分かる。さらに， 剥離の無いM 1 の方が削孔速度が遅い。この原因とし ては, 釉薬が厚いこと执よび素地が強いことのふたつが 考えられる。図-6には, 試験結果のうち, 深さ $2 \mathrm{~mm}$ 以内の表層部を拡大して示す。勾配が緩い部分が釉薬部 分を示し, 勾配が急になったところから素地が始まると 考えられる。

釉薬の厚さの推定値は, M 1 の健全部が $0.64 \mathrm{~mm}$ 之 $0.77 \mathrm{~mm}$ ，貫入部が $1.0 \mathrm{~mm}$ に対し，M 2 では健全部 $0.53 \mathrm{~mm}$, 浮き部 $0.6 \mathrm{~mm}$ となっている。すなわち, 釉薬に浮きが発生している M 2 の方が薄めであり, 釉 薬が剥離している部分の付近は $0.15 \mathrm{~mm}$ および 0.34 $\mathrm{mm}$ とさらに釉薬が薄くなっていることが分かった。

次に, 図-5 から釉薬部分を取りのぞいて素地のみに した場合の測定結果を図-7に示す。釉薬剥離が起きて いるM 2 の方が全体的に素地の削孔速度が速く（強度 が小さく), なかであ釉薬剥離部分が特に削孔速度が速 い(弱い)ことが分かる。

（2）含浸強化剤の浸透性評価

平物テラコッタをカットし，健全な素地を露出させた あのに含浸強化剂を塗布した場合の測定結果を図-8に 示す。図-8によれば，表-2 における配合 No.1 の含浸 強化剂を塗布した箇所の削孔速度は無処理と同様であっ

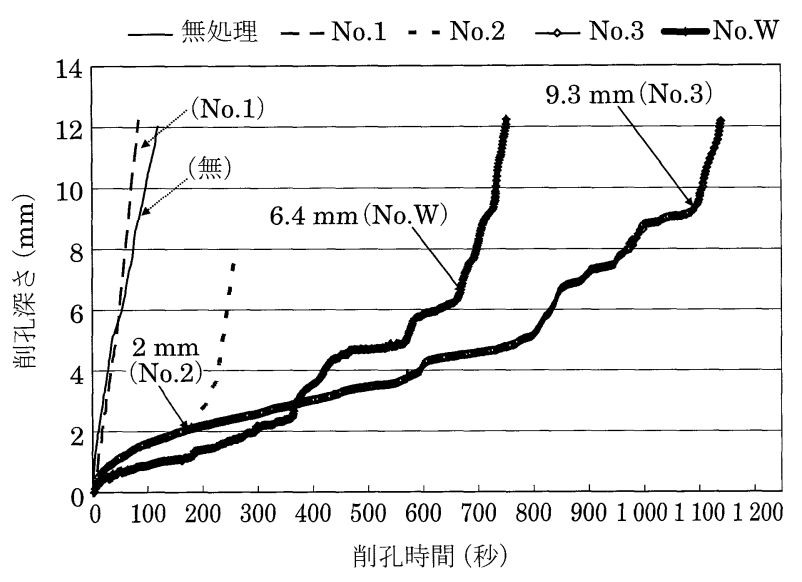

図-8 含浸補強処理後の削孔試験結果

た。これは薬剤が素地内に浸透していないか，薬剂によ る強化がなされていないことを示している。しかし，配 合 No.2 は $2 \mathrm{~mm}$ まで, No.W は $6.4 \mathrm{~mm}$ まで, No.3 は $9.3 \mathrm{~mm}$ までの削孔速度が小さくなっている。この 深さは薬剂の浸透深さを示していると考えられる。この 結果弜判断すると, 今回用いた含浸強化剂は, 強化剂 としては浸透性がかなり高いものであるといえる。

\section{4 小 括}

開発中の小径ドリル型削孔試験機を用いて，テラコッ 夕の劣化度㧍よび含浸強化剤の効果に関する検討を行っ た。その結果，以下のことが分かった。

(1)釉薬剥離は, 窯出しの時点で釉薬が薄く, 焼成後の 素地の強度が弱い場合に起きやすい。

(2)釉薬の貫入は，窯出しの時点で釉薬が厚い場合に入 りやすい。

(3)今回評価した配合 No.3の含浸強化剤は, 健全なテ ラコッタ素地に対して約 $9 \mathrm{~mm}$ 浸透した。このこ とから，劣化して脆弱になった部分の補修剤として 十分有効であると思われる。

以上の上うに，本試験機を用いることで，テラコッタ の深さ方向の物性之劣化状況抢よび劣化原因の推定，そ の他含浸強化剂の補強効果の評価ができることが分かっ た。しかし，一方で試験方法に関して以下の問題点も明 らかになった。

(1)使用開始段階において, ビットの削孔効率が不安定 なため, 安定するまで予備削孔等の前処理を行う必 要があった。

(2)ビットの寿命および長時間使用時の削孔効率の低下 性状が不明であった。

(3)ビットごとに削孔速度の個体差があった。

(4)使用した供試体がテラコッタであったため, 部位ご との強度が必ずしも均一でない可能性があり, 試験 值のバラッキの原因が特定できなかった。

以上の結果を受けて, 削孔ビットの改良および均質供 試体を用いた絶対強度の推定を試みた。その概要を以下 に紹介する。 
4. セメントペースト硬化体の強度推定 ${ }^{15) ~ 17) ~}$

\section{1 試 験 目 的}

被測定体に均質性の高いセメントペーストを用い，圧 縮強度の推定を試みた。また，試験に先立ち，先端ビッ トの削孔能力の安定性を改善するための改良を行った。

\section{2 削孔能力安定化のためのビットの改良}

前項で述べた削孔速度の不安定な現象は, ダイヤモン ドビットの砥粒が同一粒度のなかでも形状が異なると削 孔效率が違うことに起因していると考えた。すなわち, 鋭角が多く飛び出た砥粒は削孔速度が速く, 鈍角が多い 砥粒は削孔速度が遅くなる。この点を改善すべく, ダイ ヤモンド砥粒の形状を球形に近いむのとし，粒度は\#80 とした。また，切り粉を排出しやすいようにビット先端 および側面に溝を入れ，側面を根本に向かって細くなる ようなテーパ角をつけたビットを試作した。写真-10に ビットの装着状況を示し, 写真-11にビットの先端形状 を示す。

\section{3 セメントペースト供試体の測定結果}

改良ビットを用いて水セメント比 $80 \%$ のセメントペー ストの削孔試験を行った。測定結果を図-9に示す。図一 9 によれば新しいビットを用いた削孔速度は個体差も少 なく，使用時間の影響屯少なかった。ただ表層から6 $\mathrm{mm}$ くらいまでは削孔速度はほほ一定でグラフは直線 であるが，それより削孔深さが深くなると徐々に削孔速 度が低下しており，全体でみれば 2 次関数に近い形とな る。この原因のひとつとして，供試体の強度が内部に向 かって増大していることも考えられたが，大きな孔を開 けて，供試体の内部 $6 \mathrm{~mm}$ 以深を削孔したるころ $6 \mathrm{~mm}$ 以浅上ほぼ同じ削孔速度が得られた。またセメントペー ストの試験では煉瓦やテラコッタよりこのような削孔速

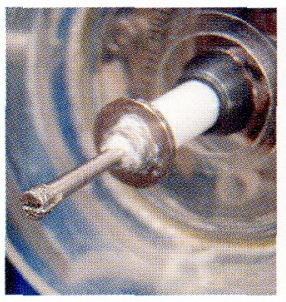

写真-10 ビットの装着 状況

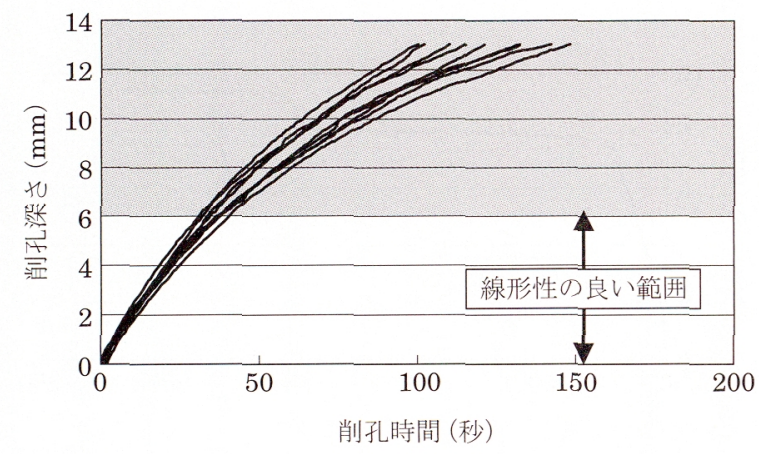

図-9 セメントペースト $(W / C=80 \%)$ に対する削孔試験結果
度低下傾向が強い。これらのことから， $6 \mathrm{~mm}$ 以深の削 孔に扮いて削孔速度が低下しているのは, 削孔時の切り 粉が孔内に残留し，ビットの削孔に対する抵抗が増大し た可能性があると判断した。さらに，この切り粉の材質 が焼き物よりセメント硬化体の方が，より抵抗が大きい 上む推定された。したがって，それを補正するため以下 の2つの方法を考案した。

No.1：削孔深さに伴う削孔能力の低下を補正する方法

No.2：削孔能力が良好な範囲のデータのみを用いる方 法

ここでは，紙面の都合上，No.1の方法によるセメン トペーストの強度評価について紹介する。

\section{4 削孔能力の低下の補正}

被削孔体が部まで均一な強度の場合に望ましい測定 結果は, 削孔速度が一定で, 削孔時間と削孔深さの関係 が 1 次関数で表されるようになることである。しかし前 項で示したように試験機の現状の特性では, 均一材料で も削孔速度は 2 次関数で近似される。そのため, この実 測值を削孔開始時の近似曲線式の接線に補正し, 削孔速 度を強度に変換することとした。

\section{(1) 試験方法}

先端ビットは, 写真-11で示したものとし, 被削孔用 供試体はセメントペースト供試体（角柱体：40 × $40 \times$ $160 \mathrm{~mm}$ ）とした。表-4 に調合と压縮試験結果を示す。

ドリルの回転数は $4000 \mathrm{rpm}$ とし, 各強度ごとに 3 本 の供試体について削孔を行った。削孔回数は各供試体ご とに 10 回の計 30 回とした。な打供試体は, 脱型後 4 力 月間水中養生し，削孔試験は水中から上げた直後に表面 の水分のみ拭き取って内部湿潤状態で行った。

\section{表-4 セメントペースト供試体の調合と圧縮強度}

\begin{tabular}{|c|c|c|c|c|c|c|}
\hline \multirow{2}{*}{ No. } & \multirow{2}{*}{$W / C$} & \multicolumn{3}{|c|}{ 単位量（g/L） } & \multirow{2}{*}{ 養生・材齢 } & \multirow{2}{*}{$\begin{array}{c}\text { 圧縮強度 } \\
(\mathrm{MPa})\end{array}$} \\
\hline & & 水 & セメント & 増粘剂 & & \\
\hline C-100 & 1.0 & 760 & 760 & 7.65 & \multirow{4}{*}{$\begin{array}{c}\text { 水中養生 } \\
\text { • } \\
28 \text { 日 }\end{array}$} & 9.5 \\
\hline C-90 & 0.9 & 740 & 823 & 5.88 & & 12.8 \\
\hline $\mathrm{C}-80$ & 0.8 & 717 & 896 & 4. 12 & & 17.2 \\
\hline$C-60$ & 0.6 & 655 & 1092 & 2. 49 & & 36.2 \\
\hline
\end{tabular}

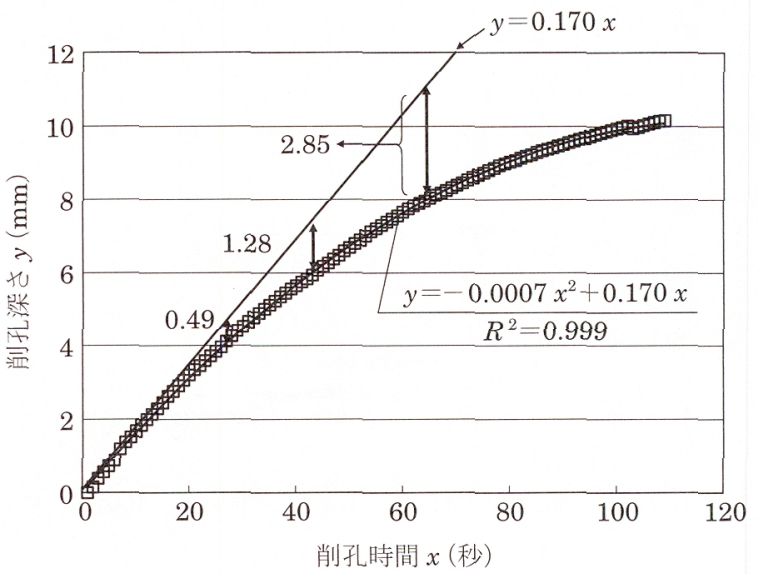

図-10 C-60 供試体の削孔試験結果 


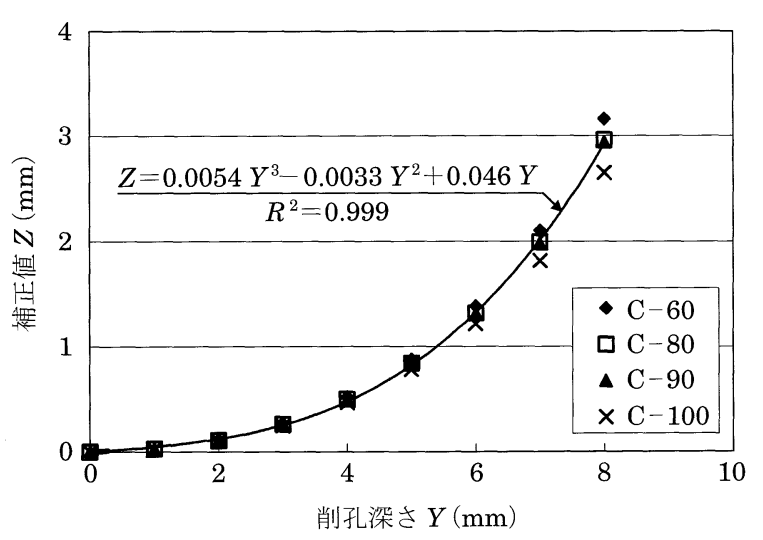

図-11削孔深さによる補正值

（2）試験結果と検量線の作成

試験結果の一例（C-60，4 回目）を図-10 に示す。測 定結果を 2 次関数で近似し, 削孔時間 $x=0$ 時の微分係 数 ( $x=0$ 時の接線勾配) を削孔開始時の削孔速度之見 なせば，その值は $0.170 \mathrm{~mm} / \mathrm{s}$ となる。削孔開始時の削 孔抵抗が内部まで同一であるとした場合, 削孔深さ $y$ は $y=0.170 x$ で表すことができる。また近似曲線式の 第 1 項 $\left(-0.0007 x^{2}\right)$ は削孔時間 $x$ 秒に抢ける削孔深さ $y$ の実測值と上記の 1 次式との差を表している。ここで, 深さ $4 \mathrm{~mm}, 6 \mathrm{~mm}, 8 \mathrm{~mm}$ 時点での縦軸の差を図-10 中 に示したが，この值（補正值 Z) を他の強度の供試体に ついても計算した結果を図-11 に示す。図-11によれば, すべての強度の供試体において各深さ時点での差はほぼ 等しくなっている。このことから削孔速度の低下現象は, セメントペーストを対象とした場合の一定の現象として 捉えることができると考えられた。

図-11に示した削孔速度低下の補正値は，ほぼ式 (1) で表すことができる。

$$
Z=0.0054 Y^{3}-0.0033 Y^{2}+0.046 Y
$$

ここで, $Z$ : 補正値 $(\mathrm{mm})$,

$$
Y: \text { 削孔深さ }(\mathrm{mm})
$$

すべての削孔デー夕を式 (1) で補正し, 得られた平均 削孔速度と圧縮強度の関係を図-12 に示す。両者の関係 は以下のような式 (2)によって与えられる。

$$
F_{c}=2.98 \mathrm{~V}^{-1.33}
$$

ここで, $F_{c}$ : セメントペーストの推定圧縮強度

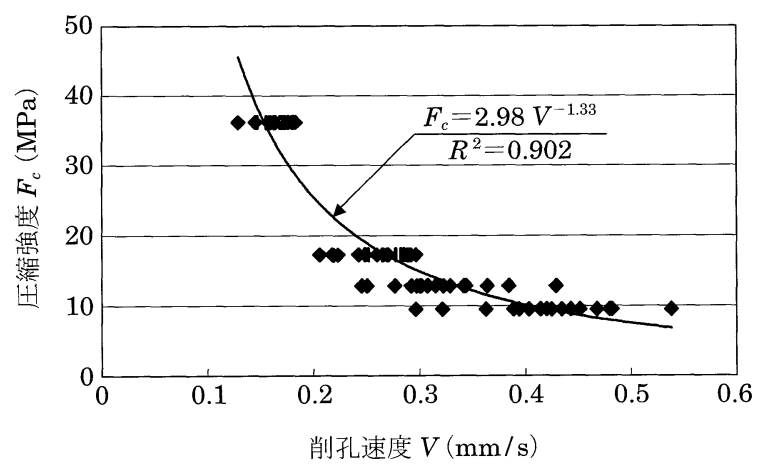

図-12 セメントペーストの削孔速度と圧縮強度の関係（検量線）

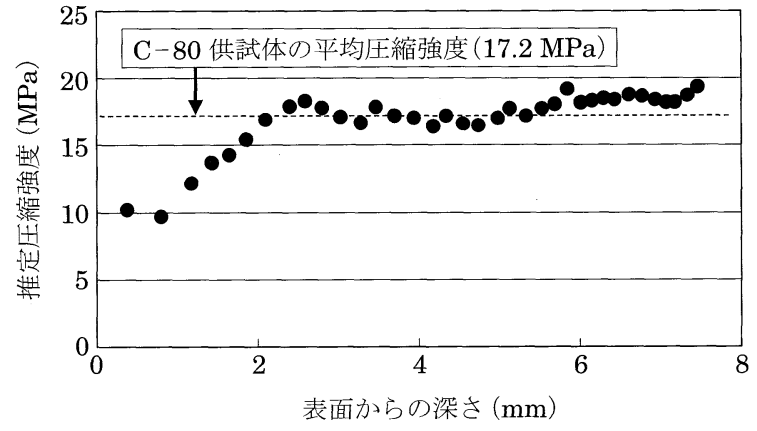

図-13 セメントペースト（C-80）の表層強度分布の推定例

$(\mathrm{MPa})$

$V$ : 平均削孔速度 $(\mathrm{mm} / \mathrm{s})$

適用範囲 : $9.5<F_{c}<36.2(\mathrm{MPa})$

$[0.16<V<0.40(\mathrm{~mm} / \mathrm{s})]$

な㧍, 以上の結果は, セメントペーストについて得ら れたものであり，材料が異なれば変化すると考えられる。

（3）表層部の強度分布の推定

一例として比較的低強度の C-80 供試体について考察 する。まず測定デー夕を式 (1) を用いて削孔位置の補 正を行う。次に削孔速度の算定時のばらつきを緩和する 目的で, 移動平均を求め, 得られたデー夕を式 (2) に よって变換したものを推定圧縮強度分布として図-13に 示す。本補正方法によ机ば $2 \mathrm{~mm}$ 以深のデー夕は，C-80 供試体の平均圧縮強度である $17.2 \mathrm{MPa}$ とほぼ一致して いる。一方, 表面から $2 \mathrm{~mm}$ 程度までが低強度となっ ていることが分かる。この傾向に関しては, 補正後に明 確となったものであり，さらに詳細な検討が必要ではあ るが，低強度のセメントペーストを 4 力月間水中養生し たことにより, 表層部付近で成分溶出が生じ, 弱化層が 生じた可能性も考えられる18)。また，その他の低強度レ ベルの供試体（C-90 および C-100）でも同様な傾向が 見られたことを付記する。

5. 今後の展開㧍よび展望

5.1 一般構造物（モルタル・コンクリート）への適用 一般構造物への展開の可能性を検討するために, モル タルに対して削孔試験を行った。図-14 は, $W / C$ が $100 \%, s / a=0.55$ のモルタルの削孔試験結果である。 図中で削孔速度が極端に遅い領域（○部）は，図-15

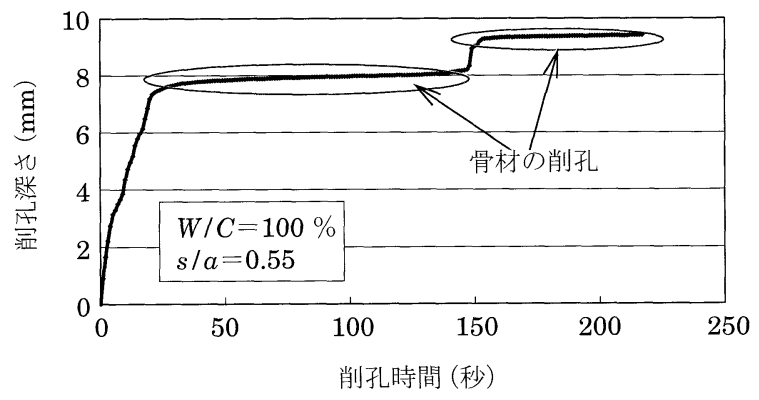

図-14 モルタルの削孔試験結果（例） 


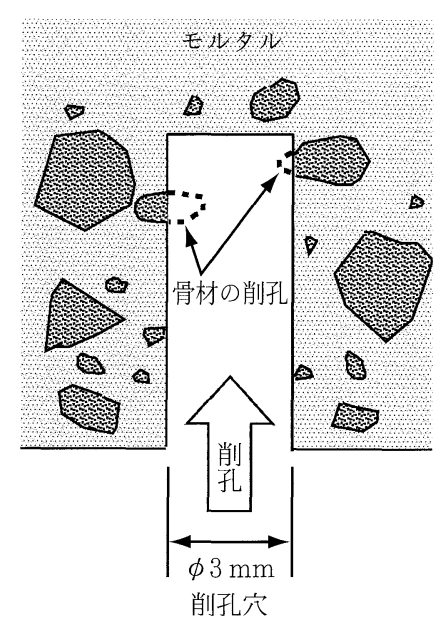

図-15 モルタルの削孔試験のイメージ

に示すように，細骨材の削孔を行っているものと考えら れる。強度評価を行うためにはこの部分を棄却しなけれ ばならない。今後はこの点についてソフトおよび運用面 で最適な方法を考えていきたい。

\section{2 歴史的建造物への適用}

アジアに扔ける寺院・仏塔等の非木造建造物では，石 造や煉瓦造で漆喰塗り仕上げとなっているあのが多い。 また，目地材料としては，石灰モルタル（漆喰）や粘土 が使用されていることが多い。これらの材料が経年によ る塩類風化や凍害で剥離・落下したり, むき出しの煉瓦 が表層から脆弱化し溶解しているもの屯散見される。こ れらの歴史的建造物の保存修理を考えるにあたり, 現状 の材料劣化状況を正しく評価すること, ならびに含浸強 化剤などによる補修効果の確認はきわめて重要である。

ここでは, 本試験方法の適用例として外壁テラコッタ の劣化診断例を示した。今後は, 非木造文化財建造物の 塩類風化をはじめ, 各種材料劣化の評価㧍よび建造物の 補修計画作成にあたり，文化的な側面をも考慮しつつ， 本試験方法のさらなる適用を考えていきたい。本研究が, 歴史的建造物の保存という分野で工学の立場から少しで あ貢献できればと考えている。

謝＼cjkstart辞 本研究に対し，ご協力およびご指導いただい た明治村館長・飯田喜四郎名大名誉教授, 文化庁文化財 部参事官付主任文化財調查官・長谷川直司氏に深く感謝 の意を表します。さらに，ご協力いただいた三重大学工 学部建築学科技術員・和藤浩氏㧍よび同修士課程・宝栄 泰紀氏, 建築学科学生・島崎友美氏, 中川陽大氏, 同卒 業生・中島尚吾氏，烌日本診断設計・平澤陽子氏，大西 郊美氏, 安井香奈子氏, 本多千絵美氏にも謝意を表しま す。

\section{参 考 文 献}

1）島田博明・小口千明・松倉公憲：レンガの塩類風化に関する一室 内実験, 筑波大学陸域環境研究センター報告, No.3, pp.59〜65, 2002

2）朽津信明・早川典子：文化財の保存を目的とした棟瓦の樹脂処理 効果に関する研究，保存科学，No.40, pp.35〜 45, 2001

3) Kuchitsu. N, Ishizaki. T, and Nishiura. T: Salt weathering of brick monuments in the Ayutthaya Site, Thailand, Engineering Geology, No.55, pp.91-99, 1999

4）西浦忠輝・石崎武志・チラポン アラニャナク・キッチャ ユホー： スコータイ遺跡のスリ・チュム寺院大仏の保存修復 (1), 保存 科学, No.38, pp.146 153, 1999

5）谷川恭雄編：コンクリート構造物の非破壊検査・診断方法，株七 メントジャーナル社, pp.21〜22, 2004.9.17

6）太田福男・太田則行：コアドリルの送り難易度による表層コンク リートの圧縮強度推定に関する実験的研究, 日本建築学会東海支 部研究報告集, 第 37 号, pp.65〜 68, 1999.2

7）太田福男・太田則行：コアドリルの送り難易度による表層コンク リートの圧縮強度推定に関する実験的研究, 日本建築学会東海支 部研究報告集, 第 38 号, pp.53 56, 2000.2

8）太田達見：ドリル削孔法によるコンクリート圧縮強度の推定法, 日本建築学会「コンクリートの試験方法に関するシンポジウム」 報告集, pp.2-75〜2-78, 2003. 11

9）湯浅 昇：引っかき傷によるコンクリートの表面強度推定, 検查 技術，pp.37 42, 2001.2

10）長谷川哲也・長谷川直司・三島直生・畑中重光・谷川恭雄 : 文化 財に用いられた石材への表層部強化処理剤の浸透性評価方法に関 する研究 (携帯式表層強度測定器の使用例), 日本建築学会大会 学術講演梗概集 (近畿), pp.23 24, 2005.9

11）長谷川哲也・畑中重光・長谷川直司・三島直生・谷川恭雄 : 新型 表層強度試験器によるテラコッ夕の強度劣化抢よび今浸強化処理 効果の評価, 日本建築什上学会大会学術講演会, pp. $155 \sim 158$, 2005. 10

12）長谷川哲也・畑中重光・長谷川直司・三島直生・谷川恭雄 : 小径 ドリル式試験器によるテラコッタの表層強度および含浸処理効果 の評価, 日本コンクリート工学協会「歴史的構造物の診断・修復 に関するシンポジゥム」, pp.101〜106, , 2006.6.9

13）長谷川哲也・三島直生・長谷川直司・畑中重光・谷川恭雄 : 小径 ドリル式試験器によるテラコッタの表層強度および含浸処理効果 の評価, 日本非破壊検査協会シンポジゥム「コンクリート構造物 への非破壊検查の展開」論文集, Vol.2, pp.441 446, 2006.8

14）長谷川哲也・畑中重光・谷川恭雄・長谷川直司：歴史的建造物の 表面から内部への連続した強度評価のための小径ドリル型削孔試 験機の開発研究, 日本建築学会技術報告集, 第 26 号, pp.421 426, 2007. 12

15）長谷川哲也・畑中重光・三島直生・谷川恭雄 : 削孔式表層強度試 験器によるセメント硬化体の強度評価, コンクリート工学年次論 文集, Vol.28, No.1, pp.1877 1882, 2006

16）長谷川哲也 -三島直生・長谷川直司 - 畑中重光 - 谷川恭雄 : 小径 ドリル式表層強度試験器によるセメント硬化体の強度評価, 日本 非破壊検查協会シンポジゥム「コンクリート構造物への非破壊検 査の展開」論文集, Vol.2, pp.421 426, 2006.8

17）長谷川哲也・畑中重光・島直生・本多千絵美 - 谷川恭雄 : 小径 ドリル型削孔試験機によるセメントペーストの圧縮強度推定一建 造物の表層強度推定手法に関する開発研究一, 日本建築学会構造 系論文集，第 621 号, pp.1 8, 2007. 11

18）菅谷秀幸・小川邦英・星野清一・後藤孝治：材齢 10 年迄の JIS モルタルの強さについて, セメント・コンクリート論文集, No.53, pp.185 191, 1999.2 